\title{
KEPEMIMPINAN PEMERINTAH DAERAH DALAM PERSPEKTIF ETIKA PUBLIK
}

\author{
Oleh : Maskan. AF. \\ email : maskanabdulfatah@yahoo.com \\ Dosen Program Studi Ilmu Administrasi Negara \\ Fakultas Ilmu Sosial dan Ilmu Politik \\ Universitas 17 Agustus 1945 Samarinda
}

\begin{abstract}
Leaders are the center of everything for those who are led, they have the capacity, ability, and integrity, and become an example and role model for their subordinates, so they must understand the ethical and moral values and be able to realize them in carrying out their leadership processes.

To get a leader as a criterion required above requires a system and process of recruitment and regeneration according to good mechanisms so that good leaders will be found. But in reality at the moment the political party as the leader cadre printing whoever will advance in the regional head election contestation must go through the party vehicles, but not all of them have carried out the pattern of recruitment and regeneration as it should be, precisely what is done is kinship politics, and instant regeneration as a result many party cadres who became a leader in the area was not able to carry out the duties and responsibilities delegated to the leader maximally, instead it was proven that several regional heads stumbled over legal problems due to misusing their positions for personal, family and group interests.
\end{abstract}

Keyword : Leadership, local government, public ethics

\section{ABSTRAK}

Pemimpin merupakan pusat dari segala-galanya bagi yang dipimpin, tak terkecuali kepemimpinan Kepala Daerah, harus memiliki kapasitas, kapabilitas, dan integritas, serta menjadi contoh dan panutan bagi para bawahannya, sehingga harus memahami nilai etika dan moral serta mampu mewujudkannya dalam menjalankan proses kepemimpinannya.

Untuk mendapatkan seorang pemimpin sebagaimana kreteria yang dipersyaratkan di atas diperlukan adanya sistem dan proses recruitmen dan 
kaderisasi sesuai mekanisme yang baik sehingga akan didapatkan pemimpin yang baik pula. Namun pada kenyataannya saat ini partai politik sebagai pencetak kader pemimpin siapapun yang akan maju dalam kontestasi Pemilu kepala daerah harus melalui kendaraan partai, namun belum seluruhnya menjalankan pola recruitmen dan kaderisasi sebagaimana mestinya, justru yang dilakukan adalah politik kekerabatan, dan kaderisasi instan akibatnya banyak kader partai yang menjadi pemimpin di daerah tidak mampu menjalankan tugas dan tanggung jawab yang dimanahkan kepadanya secara maksimal, malah terbukti beberapa kepala daerah tersandung masalah hukum akibat menyalahgunakan jabatannya untuk kepentingan pribadi, kerabat, dan kelompoknya.

\section{Kata Kunci : Kepemimpinan, Pemerintah Daerah, Etika Publik.}

\section{PENDAHULUAN}

\section{A. Latar Belakang}

Akhir-akhir ini terdapat kasus-kasus yang mengindikasikan semakin melunturnya etika sebagian pemimpin publik, hal ini ditandai semakin mengemuka dan bahkan beberapa pejabat publik yang melakukan pelanggaran etika tersebut seolah-olah menganggap bahwa kasus yang menjeratnya bukan suatu kejadian yang luar biasa, karena toh dilakukan juga oleh para pemimpin publik yang lainnyadi daerah-daerah di negeri ini. Pelanggaran etika yang terjadi dari pemimpin publik lebih banyak didominasi oleh kasus korupsi, walaupun juga ada beberapa kasus asusila dan jenis pelanggaran lain seperti nikah siriyang dilakukan oleh oknum pejabat publik.

Korupsi sudah sangat membudaya dikalangan bangsa ini seolah-olah telah menjadi kultur yang melekat dalam masyarakat yang begitu sulit untuk diubah. Korupsi telah menyebar luas tidak hanya di kalangan masyarakat bawah tetapi juga sampai tingkat atas, di kalangan birokrat rendahan sampai yang berjabatan tinggi, di kalangan wakil rakyat sampai pada rakyatnya itu sendiri.

Dari tahun ke tahun wajah pemimpin publik seperti gubernur, bupati, walikota bahkan juga pejabat politik sekelas Menteri ada yang tersangkut kasus korupsi dengan berbagai macam kasus semakin marak menghiasi headline di media cetak dan elektronik.

Munculnya banyak gerakan antikorupsi perlu diapresiasi, hanya sayangnya kebanyakan gerakan itu belum menjadi gerakan bersama untuk membasmi sampai ke tingkat akar-akar korupsi itu sendiri. Gerakan mereka cenderung parsial dan kerap terasa tidak serius, dan sebaliknya semangat pelaku korupsi yang tambah mengebu-gebu dan masih juga terus berjalan 
bagaikan gurita. Lihat saja di level-level Birokrasi dari level bawah sampai ke tingkat Pemimpinnya. Terlepas dari opini yang menggiring bahwa kasus korupsi yang dituduhkan kepada seorang pemimpin publik sering dikaitkan dengan rekayasa politik, tetapi realitanya pemimpin publik tersebut khususnya kepala daerah masuk dalam OTT dari KPK dengan bukti-bukti yang sudah dipegang oleh KPK dan sulit rasanya para pelaku akan berkelit, dan biasanya siapapun yang terkena OTT KPK rasanya sulit akan dapat lepas dari jeratan hukum.

Pada tahun 2018 saja, hingga bulan Desember sudah 21 Kepala Daerah yang terjerat kasus korupsi, melalui operasi tangkap tangan (OTT) KPK diantaranya terdapat satu orang Gubernur dan 20 Bupati/Walikota, dengan jumlah dana yang dikorupsi variatif, tetapi jumlahnya cukup fantastis.

Membudayanya kasus korupsi sebagaimana apa yang disampaikan oleh George Junus Aditjondro dalam Benny Susetyo,bahwa Soeharto memang sudah lengser tetapi rezim belum berubah merupakan fakta bahwa tidak ada kemauan politik untuk memerangi korupsi sebagai musuh bersama (2004:18).

Dengan beberapa fakta kasus korupsi tersebut, maka perlu dipertanyakan tentang makna dan wujud etika bagi para pemimpin publik khususnya kepala daerah. Integritas pemimpin publik sering dipertanyakan pada saat pemimpin tersebut terjerat kasus pelanggaran etika publik.

Sebagai pemimpin publik di daerah, para pemimpin publik menjadi teladan dan panutan serta cerminan baik bagi masyarakat maupun bagi para birokrat itu sendiri di daerah.

Masyarakat tentu saja menginginkan kepala daerah yang dipilih secara langsung itu merupakan sosok yang memiliki kemampuan, kecakapan serta integritas yang tinggi sehingga nantinya bisa mewujudkan cita-cita dan harapan masayarakat untuk meningkatkan kesejahteraan bagi masyarakatnya melalui visi, misinya yang telah disampaikan pada saat kampanye. Dengan demikian pemahaman dan penghayatan serta penerapan etika publik dalam pemerintahannya benar-benar menjadi bagian yang tidak terpisahkan dari sosok kepala daerah bahkan menjadikan acuan atau landasan bagi pemimpin publik dalam menjalankan dan memimpin suatu pemerintah daerah.

\section{B. Tujuan Penulisan}

Adapun inti dari penulisan mengenai Kepemimpinan Pemerintah Daerah dalam perspektif Etika Publik adalah mendeskripsikan dan menganalisis hal-hal yang berkenaan dengan etika publik bagi kepala daerah baik Gubernur, Bupati maupun Walikota di Indonesia dalam perspektif teori dan konsep etika dan kepemimpinan. 
Etika publik seharusnya menjadi landasan berperilaku seorang kepala daerah dalam menjalankan proses kepemimpinannya sehingga kepala daerah mampu mencerminkan sosok yang memiliki integritas tinggi dan patut untuk menjadi contoh dan panutan bagi aparatur Pemerintah yang ada di bawahnya serta masyarakat pada umumnya dalam pola pikir dan pola tindak serta perilakunya.

\section{I. KERANGKA DASAR TEORI}

\section{A. Kepemimpinan}

Menurut Inu Kencana Syaffiie dalam Ilmu Administrasi.

Secara etimologis kepemimpinan dapat diartikan sebagai berikut:

a). Berasal dari kata dasar " Pimpin " (dalam bahasa Inggris " Lead ") berarti bimbing atau tuntun, dengan begitu di dalamnya ada dua pihak yaitu yang dipimpin dan yang memimpin.

b).Setelah ditambah awalan "pe" menjadi "pemimpin" (dalam bahasa Inggris "leader") berarti orang yang memengaruhi pihak lain melalui prosesw kewibawaan komunikasi sehingga orang lain tersebut bertindak sesuatu dalam mencapai tujuan tertentu.

c).Apabila ditambah akhiran " an "menjadi "pimpinan" artinya orang yang mengepalai. Antara pemimpin dengan pimpinan dapat dibedakan, yaitu pimpinan (kepala) cenderung lebih otokratis, sedangkan pemimpin (ketua) cenderung lebih demokratis.

d). Setelah dilengkapin dengan awalan "ke" menjadi "kepemimpinan" (dalam Bahasa Inggris "leadership") berarti kemampuan dan kepribadian seseorang dalam mempengaruhi serta membujuk pihak lain agar melakukan tindakan pencapaian tujuan bersama $(2014: 106,107)$.

Pendapat lain tentang kepemimpinan disampaikan beberapa ahli berikut:

C.N.Cooley dalam Inu Kencana Syafiie " Pemimpin itu selalu merupakan titik pusat dari suatu kecenderungan, dan pada kesempatan lain, semua gerakan sosial kalau diamati secara cermat akan ditemukan kecenderungan yang memiliki titik pusat $(2014 ; 107)$.

G.U.Cleeton dan C.W.Masondalam Inu Kencana " Kepemimpinan menunjukkan kemampuan memengaruhi orang-orang dan mencapai hasil melalui himbauan emosional dan ini lebih baik dibandingkan dengan melalui penggunaan kekuasaan "(2014:107).

Dapat disimpulkan bahwa kepemimpinan merupakan kemampuan seseorang untuk mempengaruhi orang lain agar orang tersebut secara sukarela mau melakukan perintah sebagaimana yang diharapkan oleh seorang pemimpin sehingga tugas-tugas organisasi bisa berjalan dengan lancar, dengan demikian begitu pentingnya arti seorang pemimpin itu karena 
merupakan sentral dalam mengelola sumberdaya yang dimiliki dalam suatu organisasi guna mewujudkan visi organisasi tersebut.

\section{B. Pemerintah Daerah}

Pemerintah Daerah menurut Undang-Undang nomor 23 tentang Pemerintah Daerah. Bab I pasal 1 ayat (2) Pemerintah Daerah adalah penyelenggaraan urusan pemerintahan oleh pemerintah daerah dan dewan perwakilan rakyat daerah menurut asas otonomi dan tugas pembantuan dengan prinsip otonomi seluas-luasnya dalam sistem dan prinsip Negara Kesatuan Republik Indonesia sebagaimana dimaksud dalam Undang-Undang Dasar Negara Republik Indonesia tahun 1945.

Ayat (2) Pemerintah Daerah kepala daerah sebagai unsur penyelenggara Pemerintahan Daerah yang memimpin pelaksanaan urusan pemerintahan yang menjadi kewenangan daerah otonom.

\section{Etika Publik}

\section{Etika}

Etika harus selalu hadir mewarnai kehidupan seseorang dan organisasi, terlepas orang tersebut sebagai pribadi maupun sebagai pemimpin. Sejak usia dini seseorang sudah dididik oleh orang tuanya untuk belajar tentang etika baik di lingkungan keluarga, maupun dididik oleh gurunya ketika sudah menginjak usia sekolah, dan hingga usia lanjutpun tetap memegang teguh yang namanya etika, karena manusia harus hidup bermasyarakat sehingga harus dapat hidup yang selaras dengan lingkungannya. Bila etika dilanggar maka sanksi sosial dan hukum biasanya dikenakan kepada pelanggar etika, begitu juga ketika seorang pemimpin publik apakah Ketua RT dan para aparatnya melanggar etika maka sanksi sosial juga akan menghadangnya.

Menurut Salomon dalam Wahyudi Kumorotomo, etika merujuk kepada dua hal.

Pertama, etika berkenaan dengan disiplin ilmu yang mempelajari nilainilai yang dianut oleh manusia beserta pembenarannya dan dalam hal ini etika merupakan salah satu cabang filsafat.

Kedua, etika merupakan pokok permasalahan di dalam disiplin ilmu itu sendiri yaitu nilai-nilai hidup dan hukum-hukum yang mengatur tingkah laku manusia.(2009:7).

A.W.Widjaja berpendapat bahwa " etika cabang filsafat yang membicarakan tentang penilaian tingkah laku yang benar yang mempergunakan predikat-predikat kesusilaan seperti baik buruk, salah tidak salah dan lain sebagainya (1993:18). 
Bertens ( Sofyan S Harahap, 2010: 23), mendefinisikan, secara sederhana, etika adalah ilmu tentang apa yang dapat dilakukan atau ilmu tentang adat kebiasaan.

Lebih jauh dijelaskan Bertens terdapat tiga arti etika.

Pertama, nilai-nilai dan norma-norma moral yang menjadi pegangan bagi seseorang atau suatu kelompok dalam mengatur tingkah lakunya atau tingkah laku kelompoknya.

Kedua, kumpulan asas atau nilai moral.

Ketiga, ilmu tentang yang baik atau buruk.

\section{Publik}

Publik, Inu Kencana Syafiie mengartikan bahwa Publik berasal dari bahasa inggris public yang berarti umum, masyarakat atau negara. (2010:17)

\section{Moral dan Etika Pemimpin Publik.}

\section{Bidang Ideologi}

Rendahnya kesadaran Pemahaman dan Penerapan terhadap nilainilai Pancasila

Dalam kaitan dengan ideologi Pancasila, sebagaian masyarakat termasuk juga sebagian pejabat publik masih rendah kesadarannya dalam pemahaman, penghayatan dan penerapan Pancasila sebagai ideologi negara. Hal ini tercermin dalam pola pikir dan pola tindak atau perilaku dalam kehidupan bermasyarakat, berbangsa, dan bernegara. Misalnya, masih terdapatnya seorang pemimpin yang belum benar-benar menjalankan pola kepemimpinannya berdasarkan nilai-nilai yang tersirat dan tersurat pada nilai-nilai sila Pancasila yang sudah diyakini oleh seluruh bangsa Indonesia kebenarannya dan kebaikannya sehingga disepakati dan dijadikan sebagai dasar negara dan ideologi negara yang harus dijadikan sebagai sumber hukum dalam pola kehidupan berbangsa dan bernegara.

Dalam pembahasan mengenai manifestasi dari nilai sila dari Pancasila sebagai etika politik dan kepemimpinan, kita tidak bisa terlepas dari prinsip-prinsip dasar Pancasila sebagai etika politik. Secara garis besar, seorang pemimpin bisa mengambil lima nilai dasar Pancasila yang dijadikan sebagai prinsip-prinsip dalam menjalankan proses kepemimpinannya.

\section{Bidang Politik}

Proses reformasi yang dimulai sejak tahun 1998, dimana mahasiswa sebagai pendukung utamanya dengan menuntut adanya perubahan mendasar dalam hal tata kelola Pemerintahan. Gerakan ini 
mengakibatkan jatuhnya Presiden Soeharto pada tanggal 21 Mei 1998 dan ditunjuknya Wakil Presiden B.J.Habibie sebagai Presiden RI yang ketiga.

Presiden Habibie melakukan reformasi yang menyeluruh dalam kehidupan ekonomi, politik, hukum, sosial budaya dan hankam secara cemerlang. Namun demikian kehidupan reformasi ternyata membuat dampak ikutan yang tidak diperhitungkan sebelumnya, yakni melahirkan dampak negatif yaitu munculnya kebebasan dalam masyarakat tanpa batas, sehingga mengarah kepada anarkisme, saling curiga antar sesama, antar elit politik yang seharusnya moral dan etika politiknya menjadi contoh masyarakat. Hal ini menunjukkan bahwa moral dan kebersamaan elite politik masih rendah, sehingga masih mementingkan kepentingan pribadi dan kelompoknya.

\section{Money Politik}

Money Politic yang dilakukan oleh oknum pejabat publik dan oknum elit politik dalam meraih jabatan kepala daerah, gubernur, bupati, walikota di beberapa tempat dipertontonkan baik secara sembunyisembunyi maupun dapat terlihat tanpa merasa risih, malu serta bersalah, sehingga moral dan etika sebagian elit politik tidak tahu lagi membedakan antara yang halal dan haram dan antara yang benar dan salah. Hal ini menunjukkan moral kejujuran dan integritas yang didasarkan pada tuntutan ketaqwaan kepada Allah Tuhan Yang Maha Esa masih rendah sehingga sebagian mereka masih belum bisa membedakan yang hak dirinya dan mana hak orang lain, mana uang halal dan mana uang yang haram. Hal ini diperparah juga karena sebagian masyarakat sudah terbiasa disuguhi tontonan yang tidak bisa dijadikan sebagai tuntunan setiap ada pelaksanaan Pilkada maupun Pemilu yang lainnya selalu ada oknumoknum yang menjanjikan atau malakukan politik uang demi terpilihnya calon yang diusung sebagai pejabat publik. Hal-hal inilah yang oleh Menteri Dalam Negeri mengusulkan kepada parlemen agar pelaksanaan Pemilu Kepala Daerah secara langsung dievaluasi dengan alasan besarnya biaya politik ketika seseorang mengikuti kontestasi pada Pemilu Kepala Daerah.

\section{Pemahaman terhadap Etika Bernegara}

Proses reformasi berlangsung begitu cepat tanpa adanya perencanaan politik yang matang, sehingga dalam transformasinya muncul berbagai hambatan, diantaranya muncul sebagian elite-elite politik tanpa melalui proses pengkaderan yang selektif dan kompetitip sehingga menghasilkan kader yang handal. Mereka diuntungkan oleh situasi dan kondisi saat itu yang mengakibatkan para elite tersebut dapat menduduki jabatan kepemimpinan formal karena orang tuanya, 
saudaranya atau mertuanya menduduki jabatan penting di Pemerintahan, akibatnya mereka tidak faham dan mampu mengelola negara secara profesional karena ketidaktahuannya bagaimana seharusnya etika bernegara.Etika bernegara mensyaratkan pola kebersamaan diterapkan dalam kehidupan bernegara maka terbangunlah semangat kebangsaan dan semangat pengabdian dalam kepemimpinan, sehingga akan lebih mengutanmakan kepentingan nasional dari pada kepentingan pribadi dan golongan/kelompok maupun sentimen kedaerahan.

\section{Kekurang pahaman Etika Berdemokrasi}

Demokrasi membutuhkan adanya etika sportivitas dan akal fikiran yang sehat karena di dalam demokrasi berbeda dengan sistem otoriter, demokrasi membenarkan adanya persaingan Politik dalam memperoleh kekuasaan. Namun apabila persaingan politik dilakukan tanpa landasan etika sportivitas, persaingan akan mudah berubah menjadi sebuah konflik, baik konflik antar pribadi yang lebih parah lagi konflik antar kelompok, maka diperlukan pentingnya untuk memahami etika keorganisasian serta etika berdemokrasi.

\section{Belum terwujudnya pola Kepemimpinan Pancasila dalam menjalankan proses kepemimpinannya.}

Pancasila dirumuskan oleh para tokoh pendiri bangsa dihadapan sidang BPUPKI sejak tanggal 29 Mei 1945 sampai dengan tanggal 01 Juni 1945, dengan tujuan dijadikan sebagai ideologi negara sekaligus sebagai pandangan hidup dan pedoman hidup bangsa Indonesia, agar dimengerti dan dipahami serta dilaksanakan dalam wujud pola pikir dan pola tindak dalam kehidupan sehari-hari oleh seluruh masyarakat Indonesia tanpa terkecuali, apalagi oleh para pemimpin yang harus dijadikan contoh, teladan bagi masyarakat.

\section{Kaderisasi dan Kepemimpinan Partai Politik.}

Kaderisasi adalah suatu keniscayaan karena semua orang yang menjabat di pucuk pimpinan di organisasi manapun akan mengakhiri kepemimpinannya, baik dikehendaki maupun tidak. Dengan demikian proses kaderisasi terjadi karena adanya beberapa faktor yang menjadikan mengapa kaderisasi kepemimpinan mutlak diperlukan, diantaranya (Rivai, 2006):

a. Adanya ketentuan periode kepemimpinan seseorang dalam sebuah organisasi

b. Adanya penolakan dari anggota kelompok yang menghendaki pergantian kepemimpinan, baik secara wajar maupun tidak wajar 
c. Proses alamiah yakni usia yang menjadi tua dan kehilangan kemampuan memimpin (pensiun)

d. Kematian

e. Dapat membentuk organisasi dengan perkiraan dalam jumlah ketersediaan pemimpin yang diperlukan dimasa depan secara berkesinambungan.

Berdasarkan panduan rekrutmen dan Kaderisasi partai politik ideal di Indonesia yang disusun oleh KPK bekerjasama dengan Lembaga Ilmu Pengetahuan Indonesia.

Partai harus menciptakan pola pembinaan kader yang terprogram, terukur, sistematis, dan komprehensif serta berlaku di semua lini kader dan wilayah kader yang mencakup :

a. Adanya tata norma, aturan dan tata institusi dalam membentuk sistem pengkaderan, baik pengkaderan umum dan pengkaderan khusus.

b. Adanya model rekrutmen yang terbuka dan demokratis

c. Terdapatnya sistem evaluasi pembinaan kader yang berkesinambungan.

d. Membentuk jaringan kerja kader melalui interaksi antar kader demi meningkatkan kualitas kader agar lahir kader-kader yang loyal dan berdedikasi tinggi.

e. Perlu dilakukan affirmative action dalam merecrut dan melakukan pola pembinaan perempuan kader partai guna mencapai meningkatkan jumlah perempuan dalam partai politik, parlemen, maupun jabatan-jabatan publik. Selain itu kaderisasi pada kelompok perempuan juga berarti meningkatkan kemampuan dan ketrampilan perempuan terkait dengan peran yang dimainkan dalam partai politik, parlemen dan jabatan publik lainnya; dan

f. Model pembinaan perempuan kader partai, baik dari segi strategi pembinaan, materi pembinaan maupun metode pembinaan hendaknya dikembangkan dan sesuai dengan kebutuhan (2016:51)

\section{PEMBAHASAN}

\section{A. Kepemimpinan dan Keteladanan}

Dalam ajaran kepemimpinan Pancasila terdapat apa yang disebut dengan "TRILOGI KEPEMIMPINAN "sebagaimana yang disampaikan Adi Sujatno dalam Moral dan Etika Kepemimpinan yaitu : "Ing Ngarsa Sung Tulada, Ing Madya Mangun Karsa, Tut Wuri Handayani " (2007:18-19)

"Ing Ngarsa Sung Tulada" dalam kaitan seorang pemimpin sebagaimana teori tersebut, seorang pemimpin wajib memiliki sifat-sifat yang melekat dalam proses kepemimpinannya sebagai berikut: 
1) Berani menghadapi rintangan dan bekerja dalam merintis segala macam usaha.

2) Tabah dan sanggup bekerja yang paling berat.

3) Menegakkan disiplin diri sendiri maupun para bawahan.

4) Memberi contoh dan teladan

5) Mengabdikan diri pada kepentingan umum dan segenap anggota organisasi

6) Bijaksana dalam memberikan petunjuk, nasehat dan pertimbanganpertimbangan

7) Berani menjadi ujung tombak dalam setiap usaha dan perjuangan

8) Berdiri paling depan dan memiliki sifat : teguh dan tangguh

Dari berbagai sifat-sifat yang dipersyaratkan di atas secara garis besar, sebenarnya dapat dirangkum bahwa intinya seorang pemimpin harus dapat dijadikan sebagai suri dan teladan bagi para bawahannya.

Di Indonesia dikenal dengan kepemimpinan yang paternalistik, bapakisme, maka seharusnya seorang tokoh dalam hal ini pemimpin pemerintahan apakah Gubernur, Bupati atau Walikota di suatu daerah senantiasa dapat dijadikan sebagai rujukan, panutan. Sehingga pola pikir, pola tindak dan perilaku yang dikerjakan, yang diperbuat senantiasa menjadi rujukan bagi seluruh bawahannya di organisasi manapun keberadaannya. Selain itu juga dapat dijadikan rujukan dan panutan secara luas bagi masyarakat yang dipimpinnya. Masih tergolong banyaknya oknum kepala daerah yang terseret kasus korupsi (mengambil uang negara), kolusi (bekerjasama saling suap-menyuap) dan nepotisme (membantu keluarga, anak dan saudara dalam mendudukkan pada suatu jabatan tertentu), nampaknya masih mendarah daging dan hidup subur di Indonesia mulai dari level Pemimpin tingkat atas sampai ke level bawah melakukannya dengan teknik dan cara yang berbeda-beda antara satu daerah dengan daerah yang lainnya, namun prinsipnya sama. Seharusnya ini tidak boleh terjadi karena bagaimanapun seorang pemimpin sudah membuat kontrak dengan rakyatnya ketika maju dan melakukan kampanye secara terbuka kepada khalayak, sehingga janji itu wajib ditepati dan diwujudkan dalam bentuk visi, misi untuk mensejahterakan masyarakat.

\section{B. Etika Kepemimpinan Publik}

Pada bab sebelumnya sudah dibahas teori tentang etika, pada dasarnya etika secara umum diartikan suatu kebiasaan atau adat istiadat yang berkenaan dengan perbuatan baik atau tidak baik, perbuatan yang mengandung arti kebenaran atau salah, kewajaran atau ketidakwajaran.

Etika merupakan refleksi dari moral, yang merupakan hasil pemikiran atau ilmu tentang interaksi manusia dengan sesama manusia lainnya, serta manusia dengan lingkungannya, baik lingkungannya. Dapat 
dikatakan etika adalah filsafat mengenai moralitas, dan merupakan ilmu pengetahuan yang sifatnya normatif dan praktis serta kritis.

Etika kepemimpinan publik di Indonesia berhimpitan dengan moral kepemimpinan berazaskan Pancasila. Etika kepemimpinan merupakan manifestasi dari moral kepemimpinan, karena etika kepemimpinan publik di Indonesia merupakan implementasi dari nilai-nilai dasar Pancasila yang secara instrumental dan operasional terpatri dalam UUD NRI 1945, menurut Mashudi Darto (2001) dalam Nanat Fatah Nasir Kepemimpinan dapat dikategorikan dalam empat macam, yaitu keorganisasian, etika kelembagaan, etika kekuasaan, dan etika kebijaksanaan.

1) Etika keorganisasian

Perilaku kepemimpinan publik haruslah terbatas pada aturan keorganisasian dalam pemerintahan bernegara. Prinsip-prinsip keorganisasian yang bersifat universal, seperti Planning, Organizing, Actuating, Controlling, haruslah diterapkan secara konsisten dalam menjalankan kepemimpinan. Dengan demikian, sikap seorang pemimpin harus taa azas terhadap ketenteuan-ketentuan organisasi yang telah ditetapkan.

2) Etika kelembagaan

Gerak langkah serta dinamika kepemimpinan publik haruslah senantiasa melembaga, dan kelembagaan pemerintahan perlu akomodatif terhadap perkembangan strategis (inetrnal lembaga maupun eksternal). Aktualisasi etika kelembagaan dalam kepemimpinan publik akan menciptakan gaya kepemimpinan kolektif-konsultatif yang sangat diperlukan dalam hubungan kepemimpinan strata atas, menengah, dan bawah atau hubungan kepemimpinan tingkat pusat dan daerah di negara Indonesia.

3) Etika kekuasaan.

Etika kekuasaan menghendaki adanya keterbatasan penggunaan kekuasaan dan menghindari penyalahgunaan kewenangan.

4) Etika kebijaksanaan.

Etika kebijaksanaan identik dengan perilaku kepemimpinan yang mengutamakan keterbukaan, kreativitas, dan inisiatif serta konsistensi. (2010:66-67).

Keempat jenis etika kepemimpian nasional di atas pada hakekatnya harusnya menyatu dalam praktek kepemimpinan dari segenap komponen bangsa. Para pelaku kepemimpinan pada level suprastruktur baik Gubernur, Bupati maupun Walikota harus memiliki moral dan etika yang terkandung dalam nilai-nilai dasar Pancasila dan melaksanakannya secara konsisten dalam perilaku kepemimpinannya. 


\section{Kaderisasi dan Kepemimpinan Partai Politik}

Kaderisasi dan kepemimpinan bagaikan dua sisi mata uang yang tidak dapat terpisahkan dalam rangka pengembangan suatu organinasi atau lembaga. Kaderisasi menjadi hal yang sangat penting dalam sebuah organisasi atau lembaga, karena kaderaisasi merupakan jembatan untuk mempersiapkan para kader-kader partai untuk dipersiapkan sebagai calon pemimpin masa depan, karena kaderisasi merupakan upaya-upaya untuk menciptakan integritas dan kepribadian sehingga terbentuk kemampuan untuk mempengaruhi dan menggerakkan orang lain agar secara sukarela mau bekerja sama dan menjalankan perintah para pemimpinnya untuk mewujudkan visi dan misi organisasi.

Betapa pentingnya peran partai politik pada era Reformasi saat ini, berbeda dengan kehadiran partai politik zaman era Orde Baru yang sama sekali tidak diperhitungkan keberadaannya dalam melahirkan pemimpinpemimpin baik level Kepala Daerah maupun Pemimpin tingkat nasional.

Namun di masa Reformasi keberadaan Partai Politik sangat strategis perannya dalam rangka menyiapkan kader-kadernya untuk dipersiapkan baik sebagai anggota DPR, DPRD maupun calon-calon pemimpin baik di level Daerah maupun di level Nasional.

Kondisi saat ini kaderisasi pada partai politik masih belum merata atau bisa dibilang masih lemah, hususnya dalam pola rekruitmen dan mekanisme kaderisasi dalam internal partai politik. Saat ini pola recrutmen dan kaderisasinya masih belum terbuka, justru yang tumbuh dan berkembang adalah menguatnya politik kekerabatan, kedekatan serta perkawanan. Lihat saja beberapa partai politik baik di level Daerah maupun Nasional masih terlihat pola kekeluargaan, misalnya Bapak atau ibunya menjadi ketua Partai, anak, adik atau keluarga yang lain berada pada posisi-posisi penting di partainya dan ini bukan lagi rahasia umum.Maka dapat dibayangkan jika partai politik sebagai sumber pemimpin nasional tidak memiliki pola recruitmen yang baik, tentu akan memunculkan berbagai persoalan yang terjadi misalnya politik kekerabatan yang akhirnya akan menutup saluran atau akses bagi orang-orang yang memiliki sumberdaya yang baik namun tidak memiliki akses, akan sulit masuk di jajaran partai. Maka pola ini seharusnya dirubah agar partai politik melakukan pola recruitmen yang terbuka sehingga mendapatkan bibit-bibit di tubuh partai yang memiliki kualitas, integritas, beriman dan bertaqwa kepada Tuhan Yang Maha Esa sehingga seluruh partai akan dipenuhi calon-calon pemimpin nasional masa depan yang handal, memilki wawasan kebangsaan, memiliki komitmen atau rasa tanggung jawab dari diri sang pemimpin merupakan sikap batin atau janji yang terpatri pada sanubari seorang pemimpin untuk mewujudkan tugas pokok dan peranannya ke dalam perilakunya dalam mencapai tujuan mewujudkan suatu pemerintahan yang baik ( good governance), sesuai 
dengan prinsip-prinsip dasarnya : akuntabilitas, transparansi, keterbukaan, penegakan hukum (rule of law), dan memberikan perlakuan yang adil/perlakuan yang sederajat.

\section{A. Kesimpulan}

\section{PENUTUP}

Kasus korupsi yang masih terjadi sampai saat ini di Indonesia hususnya pemerintah daerah dikarenakan oknum pejabat tersebut tidak berpegang teguh pada etika publik yang seharusnya menjadi pegangan dan pijakan untuk pola pikir dan pola tindakan para kepala daerah. Dikesampingkannya nilai-nilai etika publik tersebut yang seharusnya menjadi pegangan dasar sehingga dapat menuntun kepala daerah mempertimbangkan nilai baik dan buruk, nilai benar dan salahnya suatu perbuatan berupa wujud kebijakan seorang kepala daerah, sehingga tidak terseret pada perbuatan korupsi baik yang sengaja dilakukan maupun tidak disengaja.

Selain itu pentingnya meningkatkan kualitas kepemimpinan merupakan suatu keharusan, sehingga seorang pemimpin dapat menyelesaikan berbagai problema yang dihadapi oleh pemerintah daerah. Untuk mendapatkan seorang pemimpin yang berkualitas tentu saja harus dimulai dari proses recruitmen dan kaderisasi yang benar.

Partai politik merupakan wadah penyedia calon-calon pemimpin baik level pemimpin nasional maupun daerah harus memiliki pola dan cara recruitmen yang baik dan benar sehingga akan dapat melahirkan kader-kader partai yang nantinya bisa menjadi pemimpin yang handal, beretika dan bermoral, sehingga akan mendapatkan pemimpin-pemimpin yang berkarakter baik, memiliki integritas dan moral serta etika yang dibutuhkan sebagai seorang pemimpin, sehingga roda pemerintahan daerah berjalan sesuai visi, misi yang telah ditetapkan, tanpa pelanggaran hukum.

\section{B. Saran}

1. Pemerintah mendorong agar partai politik memiliki pola recruitmen dan kaderisasi di lingkungan partai sehingga akan lahir pemimpin-pemimpin yang berkualitas.

2. Pemerintah memberikan dana stimulasi yang cukup berkaitan sistem recruitmen dan kaderisasi, selain itu juga memfasilitasi dengan berdirinya lembaga-lembaga husus yang dapat melaksanakan pola recruitmen dan kaderisasi pemimpin di lingkup partai politik.

3. Pentingnya modal berupa pemahaman yang mendalam setiap calon pemimpin kepala daerah terhadap nilai-nilai etika dan moral serta nilainilai agama, sehingga pola pikir dan pola tindak dalam wujud kebijakan apapun benar-benar hanya untuk kepentingan masyarakat, bukan untuk kepentingan pribadi atau golongannya semata. 


\section{DAFTAR PUSTAKA}

Adi Sujatno, Moral dan Etika Kepemimpinan, Jakarta. MontasAd 2007

A.W.Widjaja, Etika Administrasi Negara. Jakarta, PT.Bumi Aksara 1993.

Inu Kencana Syafiie, Ilmu Adfministrasi Publik. Jakarta, PT. Rineka Cipta 2010

Inu Kencana Syafiie dan Welasari, Ilmu Administrasi. Pustaka Pelajar, Yogyakarta 2014.

Insan Harapan Harahap, Kaderisasi Partai Politik dan Pengaruhnya terhadap Kepemimpin Nasional.Dosen Prodi S1 Ilmu Politik Universitas Bakrie 2017.

Nanat Fatah Natsir, Moral dan Etika Elite Politik, Yogyakarta Pustaka Pelajar 2010.

Sofyan S.Harahap, Etika Bisnis dalam Perspaktif Islam. Salemba Empat, 2010.

Wahyudi Kumorotomo,Etika Administrasi Negara, Jakarta. PT Raja Grafindo Persada 1992.

KPK bekerjasama dengan LIPI, Panduan Recrutmen \& Kaderisasi Partai Politik Ideal di Indonesia, Jakarta 2016. 